\title{
Toplum kaynaklı metisiline dirençli Staphylococcus aureus’a bağlı boyun bölgesinde karbonkül gelişen olgu
}

\section{A case with carbuncle in the neck region due community-acquired Methicillin Resistant Staphylococcus aureus}

\author{
Metin ÖZSOY $⿴$, Emine KOZAN ERMiş $\square$, Salih CESUR* $\square$, Çiğdem Ataman HATIPOĞLU曰, \\ Günay TUNCER ERTEM母, Sami KINIKLI 回
}

SBÜ Ankara Eğitim ve Araştırma Hastanesi, Enfeksiyon Hastalıları ve KlinikMikrobiyoloji Kliniği, Ankara/TÜRKIYE

\section{Öz}

Metisiline dirençli Staphylococcus aureus (MRSA)'ya bağlı toplum kaynaklı deri ve yumuşak doku infeksiyonları oldukça nadirdir. Bu yazıda, son 6 ay içinde hastanede yatış öyküsü olmayan 74 yaşında diyabetik bir kadın hastada boyun bölgesinde toplum kaynaklı MRSA bağlı olarak gelişen karbonkül sunuldu. Teikoplanin tedavisi ve aralıklı karbonkül drenajı sonrasında hastanın şikayetleri ve laboratuvar bulguları düzeldi.

Anahtar kelimeler: toplum kaynaklı metisiline dirençli Staphylococcus aureus; deri ve yumuşak doku infeksiyonu; karbonkül

\begin{abstract}
Community acquired skin and soft tissue infections due to methicillin-resistant Staphylococcus aureus (MRSA) are extremely rare. In this article, a 74-year-old diabetic woman with no history of hospitalization in the last 6 months presented with a carbuncle in the neck region due to community-acquired MRSA. After teicoplanin treatment and intermittent drainage, the patient's complaints and laboratory findings improved.
\end{abstract}

Keywords: community acquired methicillin-resistant Staphylococcus aureus; skin and soft tissue infection; carbuncle

Sorumlu Yazar*: Salih CESUR, SBÜ Ankara Eğitim ve Araştırma Hastanesi, Enfeksiyon Hastalıları ve Klinik Mikrobiyoloji Kliniği, Ankara/TÜRKiYE E-posta: scesur89@yahoo.com,

ORCID: 0000-0003-4960-7375

Gönderim: 19/08/2020 kabul: 30/11/2020

Doi: $10.18663 /$ tjcl.782469 


\section{Giriş}

Toplum kaynaklı deri ve yumuşak doku infeksiyonları oldukça sık karşılaşılan infeksiyonlardır. Bu infeksiyonlardan başıcaları; impetigo, erizipel, sellülit, nekrotizan fasittir.[1]

Karbonkül birden fazla fronkülün birbiriyle birleşmesi, apseleşerek yayılması ile oluşan, ayrı ayrı drene olması ile karakterize cilt lezyonudur. Karbonkülde bağ dokusu trabekülaları ile ayrıımış multiple apseler görülebilir. Karbonkül, ense, sırt, uyluk ve gluteal bölgede sık görülür. Karbonkül genellikle yavaş ve skar bırakarak iyileşir. Ateş ve lökositoz eşlik edebilir. Bazen toksemi veya metastatik enfeksiyona bağı ölüm görülebilir. Altta yatan hastalık olarak sıklıkla diabetes mellitus eşlik edebilir. Karbonküller ve büyük fronküllerde antimikrobiyal tedavi ile birlikte insizyon ve drenaj gereklidir. Tedavide penisilinaza dirençli antibiyotiklerden amoksisilin/ klavunat, penisilin alerjisi varsa klindamisin veya makrolidler verilebilir.[2-5] Bu yazıda, diyabeti olan 74 yaşında bir kadın hastada toplum kaynaklı MRSA'ya bağlı olarak karbankül gelişen bir olgu sunularak literatür gözen geçirildi.

\section{Olgu}

Yetmiş dört yaşında kadın hasta boyun bölgesinde kızarıklık, kaşıntı ve ağrısısişlikyakınmaları ile polikliniğe müracaat etti. Anamnezinden diyabet, hipertansiyon ve romatizmal hastalık tanılarının olduğu öğrenildi. Ayrıca, 14 sene önce geçirilmiş serebrovasküler hastalık öyküsü ve buna bağlı sağ bacakta sekel mevcuttu.

Fizik muayenesinde; ateşi $36,4{ }^{\circ} \mathrm{C}$, KB: $110 / 60 \mathrm{~mm} / \mathrm{Hg}$, boyun bölgesinde $2 \times 3 \mathrm{~cm}$ boyutlarında etrafı krutlu, karbonkülle uyumlu, pürülan akıntılı lezyon mevcuttu. Diğer sistem muayeneleri normaldi. Laboratuvar testlerinde; lökosit sayısı $22.360 / \mathrm{mm} 3$, sedimantasyon hızı 93 mm/saat, CRP 189 mg/dl idi. Biyokimyasal testleri; AST, ALT, BUN, ve kreatinin değerleri normaldi.

Hastada karbonkül bölgesinden kültür için örnek alındıktan sonra ampisilin/sulbaktam $4 \times 1.5 \mathrm{gr}$ i.v yolla başlandı.Hastada karbonkül drenaj mayinin kültüründe Staphylococcus aureus (S.aureus) üredi. Disk difüzyon yöntemiyle yapılan antibiyogram sonucunda üreyen etkenin sefoksitin ve benzilpenisilline dirençli, siproflosasin, klindamisin, eritromisin, fusidik asit, gentamisin, tetrasiklin ve vankomisine duyarlı olduğu saptandı.Boyun bilgisayarlı tomografisi '15x60x50 mm boyutlarında apse' şeklinde raporlandı.

İzole edilen suşun VITEK 2 otomatize sistemi (Biomerioux, Fransa) ile de sefoksitine dirençli olduğu belirlendi. Kültürde üreyen etkenin MRSA olması üzerine hastaya ampirik olarak başlanan ampisilin/sulbaktam tedavisi 5. günde kesilerek, teikoplanin tedavisi 12 saat arayla 400 mg intravenöz (I.V.) yükleme, daha sonra $1 \times 400 \mathrm{mg}$ I.V. idame olacak şekilde başlandı.

Hastanın anamnezinden toplum kaynaklı MRSA infeksiyonları için risk faktörü olarak başvurudan birkaç hafta önce lezyon bölgesinde çıkan sivilceyi eliyle patlattığı öğrenildi. Hastada damar içi ilaç kullanımı, saç kesimi, bakım evinde kalma, ailede sağlık çalışanı öyküsü yoktu. Anamnezinden, son 6 ay içinde hastanede yatış ve son 3 ay içinde antibiyotik kullanımı öyküsü olmadığı öğrenildi. Hastadan burunda MRSA taşıyıcılığı açısından burun kültürü alımadı. Tedaviyle hastanın klinik şikayetleri geriledi, laboratuvar bulgularında CRP 1,35 mg/ dl, lökosit sayısı ise 9280'e geriledi. Teikoplanin tedavisi 11 gün süreyle uygulanan hasta plastik cerrahi kliniğinde opere edilmek üzere oral fusidik asitle taburcu edildi.

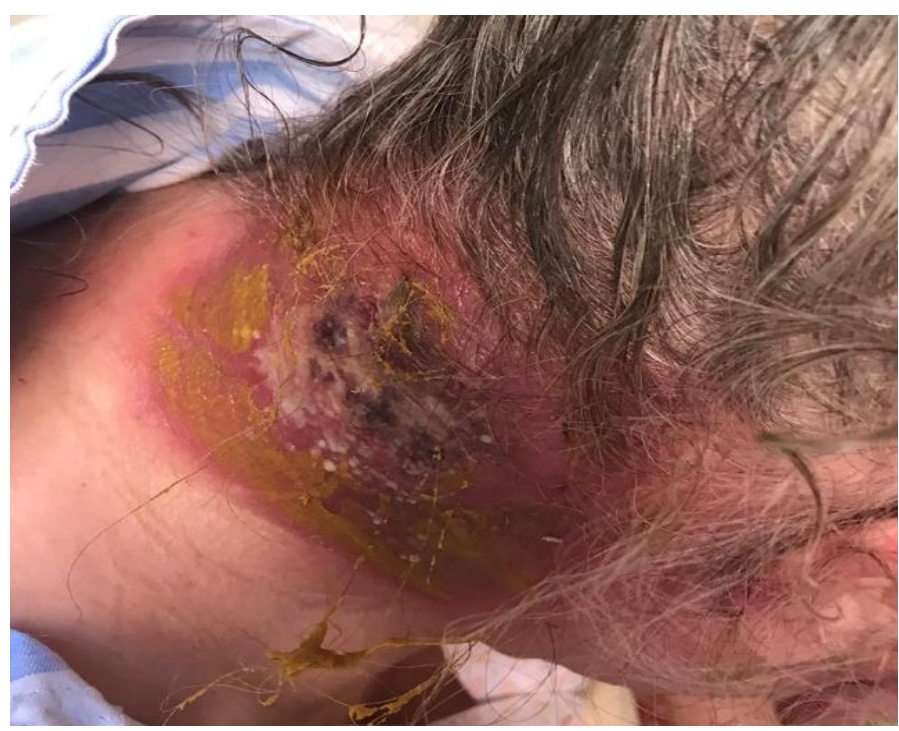

Resim 1. Tedavi öncesi hastanın boyun bölgesinde saptanan $2 \times 3$ $\mathrm{cm}$ boyutlarındaki karbonkül lezyonu

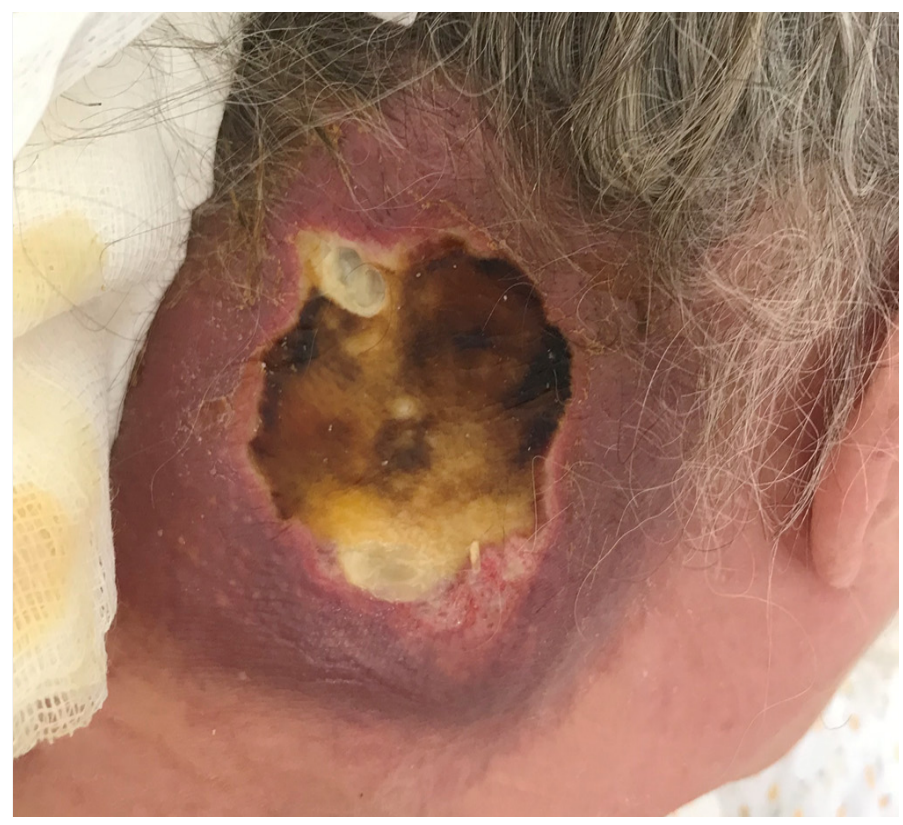

Resim 2. Antibiyotik tedavisi ve aralıklı drenaj sonrasında $6 \times 6 \mathrm{~cm}$ boyutundaki lezyonun görüntüsü 


\section{Tartışma}

MRSA, hem hastanede yatan hastalarda sağlık bakımıyla ilişkili infeksiyonlara (nozokomiyal, hastane kaynaklı) hem de sağlık bakımı ile ilişkili risk faktörleri olmayan toplum kaynaklı infeksiyonlara neden olabilen önemli bir infeksiyon etkenidir. Toplum kaynaklı metisiline dirençli S. aureus (TK-MRSA), toplumda hızlı bulaş gösterir, agresif seyirli deri ve yumuşak doku enfeksiyonları,toplum kökenli pnömoniye neden olabilir.[6]

Son yıllarda Avrupa ve Amerika başta olmak üzere tüm dünyada bakteriyel deri infeksiyonlarında toplum kökenli MRSA izolasyonunda artış bildirilmiştir .Toplum kaynaklı MRSA infeksiyonlarında bu durumda klindamisin veya kotrimoksazol kullanılabilir. Tedaviye yanıtsız olgularda kültür antibiyogram sonucuna göre tedavi başlamak gerekebilir. Şiddetli MRSA infeksiyonlarında intravenöz vankomisin ilk tercih seçenektir. [7-9] Alternatif olarak tedavide intravenöz linezolid, daptomisin, tigesiklin, telavansin ve seftarolin de tedavide kullanılabilir.[1] Toplum kökenli (TK) birkaç klonun dünya ölçeğinde yayılmasıyla, özellikle risk faktörü taşımayan genç insanlarda deri ve yumuşak doku infeksiyonlarıyla nekrotizan pnömoni olgularında artış bildrilmiştir. Bu suşların daha virülan olduğu bildirilmektedir. TK-MRSA izolatlarının Panton-Valentin lökosidin (PVL) ve stafilokoksik kaset kromozom mec (SCC mec) tip IV varlığıyla karakterize olduğu, buna karşılık HK-MRSA suşlarında SCCmec tip I-III'in yaygın olduğu bilinmektedir.[5,7] TK-MRSA infeksiyonları hastane kaynaklı (HK) MRSA'ların aksine büyük çoğunlukla deri ve deriyle ilişkili yapıların infeksiyonları şeklinde görülmektedir.[8] Toplumda sık rastlanan başlıca stafilokokal deri infeksiyonları; impetigo, folikülit, furonkül, apse ve selülit şeklinde sıralanabilir. S.aureus'a bağlı deri infeksiyonlarında hazırlayıcı faktör özellikle S. aureus burun taşıyıcılığıdır.[10]

Dünyanın hemen her bölgesinde TK-MRSA'ya bağlı infeksiyonlar artmaktadır.[6,11,12]

Almanya'da yapılan bir çalışmada TK-MRSA suşlarının PantonValentine leukocidin toksini taşıdığı, suşlarda kinolon, klindamisin, ve makrolid direnci yaygın iken, trimetoprimsulfametoksazol, tetrasiklin, mupirosin, klorheksidin ve fusidikasit direncinin ise düşük olduğu bildirilmiştir.[11]

Ülkemizde poliklinik ve yatan hastalarda yapılmış bir çalışmada infeksiyonlardan 285, kontrol grubu olarak da diğer infeksiyonlardan 161 S. aureus suşu izole edilmiş; deri ve yumuşak doku infeksiyonu olan hastalar arasında \%20.3 (n: 58), kontrol grubunda \%24.2 ( n:39) MRSA saptanmıştır. Her iki grup arasında SCC mec tip paterni açısından istatistiksel fark saptanmazken, hiçbir MRSA suşunda PVL tespit edilmemiştir. SCC mec tip IV taşıyan üç suş deri ve yumuşak doku infeksiyonlarından izole edilmiştir. Bu üç suştan ikisinde SCC mec tip IVa varlığı gösterilmiş olup biri submandibüler apse nedeniyle serviste tedavi alan bir hastadan yatışının ilk günü alınan örnekten izole edildiğinden dolayı TK-MRSA olarak kabul edilmiştir.[12] Sunduğumuz olguda son 6 ay içinde hastanede yatış öyküsü ve son 3 ay içinde antibiyotik kullanımı öyküsü olmaması nedeniyle toplum kaynaklı MRSA infeksiyonu olarak değerlendirildi. Sunduğumuz olguda altta yatan hastalık olarak diabetes mellitus mevcuttu. Olguda izole edilen MRSA suşunda moleküler yöntemlerin çalışılamaması çalışmamızın kısıtlılığı idi.

\section{Sonuç}

Sunduğumuz olguda olduğu gibi karbonkül gibi toplum kaynaklı cilt infeksiyonlarında toplum kaynaklı MRSA suşlarının da etken olabileceği akılda tutulmalı, mutlaka lezyondan örnek alınarak kültür ve antibiyotik duyarlılık testleri yapılarak tedaviye karar verilmelidir.

\section{Çıkar çatışması/finansal destek beyanı}

Bu yazıdaki hiçbir yazarın herhangi bir çıkar çatışması yoktur. Yazının herhangi bir finansal desteği yoktur.

* Makale için hastadan aydınlatılmış onam belgesi imzalatıldı.

\section{Kaynaklar}

1. Clebak KT, Malone MA. Skin infections. Prim Care Clin Office Pratice 2018; 45: 433-54.

2. Karaoğlan İ. Bakteriyel deri ve yumuşak doku infeksiyonları . https://www.klimik.org.tr/wp-content/uploads/Bakteriyel-Derive-Yumusak-Doku-infeksiyonları.pdf

3. Çetin B. Deri ve yumuşak doku infeksiyonları-Tedavi http://file. atuder.org.tr/_atuder.org/fileUpload/

4. Stevens DL, Bisno AL, Chambers HF et al. Practice guidelines for the diagnosis and management of skin and soft-tissue infections. Clin Infect Dis 2005; 41: 1373-406.

5. Pasternack MS, Swartz MN. Cellulitis, necrotizing fasciitis, and subcutaneous tissue infections. In: Mandell GL, Bennett JE, Dolin R (eds). Principles and Practice of Infectious Diseases. 7th ed. Philadelphia: Churchill Livingstone, 2010:1289-312. 
6. Kale P, Dhawan B. The changing face of community-acquired methicillin-resistant Staphylococcus aureus. Indian J med Microbiol 2016; 34: 275-85.

7. Yaylı S. Sık Görülen Bakteriyel Deri İnfeksiyonları. Türk Derm 2011; 45: 104-8.

8. Elliott DJ, Zaoutis TE, Troxel AB et al. Empiric antimicrobial therapy for pediatric skin and soft-tissue infections in the era of methicillinresistant Staphylococcus aureus. Pediatrics 2009; 123:959-66

9. Ladhani S, Garbash M. Staphylococcal skin infections in children: rational drug therapy recommendations. Paediatr Drugs 2005; 7: 77-102.

10. Karapınar BA, Yılmaz $M$, Ömeroğlu $M$,Erbudak E, Köse AA, Aydın D. Pyodermisi Olan Hastalarda Toplum Kökenli Metisiline Dirençli Staphylococcus aureus Sıklığının ve Burun Taşıyıcılığının Belirlenmesi. Klimik Dergisi 2018; 31: 115-9.
11. Klein S, Menz MD , Zanger $P$, Heeg K, Nurjadi D. Increase in the prevalence of Panton-Valentine leukocidin and clonal shift in community-onset methicillin-resistant Staphylococcus aureus causing skin and soft-tissue infections in the Rhine-Neckar Region, Germany, 2012-2016. Int J Antimicrob Agents 2019; 39: 261-7.

12. Gülmez D, Sancak B, Ercis S, Karakaya J, Hasçelik G. Toplumdan kazanılmış ve nozokomiyal Staphylococcus aureus suşlarında SCCmec tiplerinin ve Panton-Valentine lökosidin varlığının araştırılması: deri ve yumuşak doku enfeksiyonları ile diğer enfeksiyonların karşılaştırılması. Mikrobiyol Bül 2012; 46: 341-51. 